\title{
Physiological Parameters of Pigs Raised with and without Environmental Enrichment
}

\author{
Carlos Syllas Monteiro Luz ${ }^{1}$, Leonardo Atta Farias², José Luiz Leonardo Araujo Pimenta ${ }^{3}$, \\ Joisiane da Silva Santos ${ }^{4}$, Richard Átila de Sousa ${ }^{1}$, Luciana Pereira Machado ${ }^{1}$, Leilane Rocha Barros Dourado ${ }^{2}$, \\ Geraldo Magela Côrtes Carvalho ${ }^{5} \&$ Severino Cavalcante de Sousa Júnior $^{1}$ \\ ${ }^{1}$ Programa de Pós-graduação em Ciência Animal, Universidade Federal do Piauí, Teresina, Piauí, Brazil \\ ${ }^{2}$ Programa de Pós-graduação em Zootecnia, Universidade Federal do Piauí, Bom Jesus, Piauí, Brazil \\ ${ }^{3}$ Bacharelado em Zootecnia, Universidade Federal do Piauí, Bom Jesus, Piauí, Brazil \\ ${ }^{4}$ Médica Veterinária, Universidade Federal do Piauí, Bom Jesus, Piauí, Brazil \\ ${ }^{5}$ Embrapa Meio Norte, Teresina, Piauí, Brazil \\ Correspondence: Carlos Syllas Monteiro Luz, Departamento de Zootecnia, Universidade Federal do Piauí, \\ Teresina, PI, 64049-830, Brazil. Tel: 55-89-8116-4119. E-mail: syllaszoot@yahoo.com.br
}

Received: January 9, 2016

doi:10.5539/jas.v9n4p176
Accepted: February 20, $2017 \quad$ Online Published: March 15, 2017

URL: https://doi.org/10.5539/jas.v9n4p176

\begin{abstract}
Ethical and commercial issues are associated with animal welfare in pig farming, in that sense, the objective of this work was to evaluate physiological and blood parameters in addition to weight gain in pigs raised with and without sunlight and environmental enrichment (EE), as well as to correlate physiological and environmental parameters as welfare indicators. Twenty-four pigs distributed in a randomized block design with a $2 \times 2$ factorial arrangement were used. Blocks were represented by shifts (morning and afternoon), and factors by the presence or absence of EE and sunlight. Blood and environmental parameters of thermal comfort, in addition to weight gain, were registered. Physiological parameters showed to be shift dependent $(p<0.05)$, with the afternoon shift being superior when compared to the morning shift, thus indicating climate influence. Weight gain showed significant interactions $(\mathrm{p}<0.05)$ in the presence and absence of sunlight and EE in the stalls. Temperature correlated positively with the physiological parameters. Moisture showed negative correlations with physiological parameters. The packed cell volume was lower $(\mathrm{p}<0.05)$ in the presence of EE. The EE provides physiological well-being and weight gain for pigs in the nursery stage, especially when sunlight was absent in the stalls.
\end{abstract}

Keywords: temperature, thermal comfort, blood parameters, respiratory rate

\section{Introduction}

Animal welfare has relevance not only as an ethical matter, but also as a tool to access new markets, consequently any animal farm which pursues sustainability should maximize welfare in order to maximize the expression of animals' potential (Poletto et al., 2011; Velarde et al., 2015). One of the greatest challenges in pig production is to provide conditions of well-being while still remaining competitive in the market, since the animals are produced in small areas without environmental conditions to express their normal behavior (Temple et al., 2011).

Pig production is accomplished mostly under intensive farming systems, with predominance of confinement, as a mean for optimizing the productive and financial performance. In order to establish a production system with healthy condition, techniques which benefit the normal activities of the animals in each of their life stages are to be implemented, bearing in mind that the applicability of animal welfare techniques must be based on a solid scientific study (Kiefer et al., 2009; Velarde et al., 2015).

Environmental enrichment is an alternative which allows animals to express their normal behavior and thereby reduce physiological stresses produced by climatic variations and facilities. It targets to increase the quality of life for animals farmed under intensive systems, through the identification and provision of environmental 
stimuli needed to reach their psychological and physiological well-being and to improve meat production (Campos et al., 2010; Oliveira et al., 2016).

When animals are under heat stress, they tend to find ways to reduce it through physiological regulatory mechanisms, but in doing so the animals use energy that otherwise would be used for production, with a negative result for the production system (Smulders et al., 2006; Fagundes et al., 2008). Environmental factors influence the production level of animals, therefore this is an important subject of study, once less stressful environmental conditions may result in a maximum yield. Pigs have a higher weight gain when rised in comfortable environments (Kiefer et al., 2010).

Thermoneutrality is a range in which the animals can express its productive potential without using energy for the sake of thermoregulation. Under tropical weather conditions bioclimatic studies are necessary due to huge temperature variations affecting the physiological welfare of pigs. In this sense, we intended to evaluate physiological and blood parameters, in addition to weight gain, in the nursery stage of pigs raised in the presence or absence of sunlight and environmental enrichment. Moreover, we intended to correlate physiological and environmental parameters within facilities, as indicators for animal well-welfare.

\section{Method}

\subsection{Location of the Experiment and Ethical Issues}

The experiment was performed at the pig farming sector from Bom Jesus Technical School (CTBJ) at the Federal University of Piauí (UFPI), Campus Professora Cinobelina Elvas, from October until December 2014. The municipality has the following geographical coordinates: latitude $9^{\circ} 4^{\prime} 27^{\prime \prime}$ South, longitude $44^{\circ} 21^{\prime} 30^{\prime \prime}$ West and $277 \mathrm{~m}$ of altitude.

The climate is dry sub-humid with summer rainy season lingering until autumn (Andrade Jr et al., 2005). The rainy season starts in November ending in April, and a dry season occurs from May to October. This study was approved by the Ethics Committee on Animal Experiments at UFPI with protocol number 058/14.

\subsection{Animals, Design, Treatments and Environmental Enrichment}

Twenty-four castrated males, with average weight of $15.27 \pm 3.73 \mathrm{~kg}$, originated from crossing of Agroceres PIC $\times$ Piau lineage, from the CTBJ pig farming sector were used. Randomized blocks (DRB) in $2 \times 2$ factorial arrangement were used for experimental design, with a block represented by shifts (morning and afternoon), and factors being the presence or absence of environmental enrichment (EE) and incidence of sunlight.

Four stalls were used, in which the animals were randomly assigned at a proportion of six animals per stall, the replicates consisted of animals housed in the stalls. In two of the four stalls, the incidence of sunlight was allowed to up to $70 \%$, with one of the stalls including the presence of EE. The remaining two stalls did not received sunlight, with one of the stalls also having the presence of EE.

The environmental enrichment devices consisted of ethylene terephthalate (pet) bottles with a volume of 2 liters each; the bottles were half-cut and then the upper ends of both bottles were connected. For better connection a transparent tape (polypropylene $38 \mathrm{~mm}$ ) was used, wrapped in between the bottle's ends. Then three of these devices were hanged from a nylon string at a height of the animals' nose and five devices were placed in the floor, according Campos et al. (2010).

\subsection{Physiological, Blood and Environmental Parameters}

The animals were housed in the experimental stalls 10 days after weaning, thus avoiding the post weaning stress period. After five days for adaptation to the new environment, the EE devices were installed and the measurements of the variables started. The parameters measured consisted of physiological, blood and environmental parameters. In order to obtain the data, 10 sampling collects were performed from 7:00 to 09:00 am, corresponding to the morning shift and from 13:00 to 15:00 pm, corresponding to the afternoon shift, according Manno et al. (2005) and Kiefer et al. (2009).

Climate variables were measured 20 minutes after the beginning of the first observation for each sampling collect, working with the average of the observed values. Blood parameters were not evaluated regarding shifts.

Physiological parameters measured were: respiratory rate (RR), by means of counting the movements per minute (mov/min) of the pig flank during 15 seconds and adjusting these values for 60 seconds and the rectal temperature (RT), using a digital clinical thermometer inserted into the rectum of the animals for one minute, according Farias et al. (2008). 
Heart rate (HR) was measured using a clinical stethoscope at the height of the third rib on the left side of the pig's body, measuring heart rate during 15 seconds and adjusting these values to beats per minute (bpm). At the beginning and the end of the experiment the animals were weighed on a digital scale to check the weight gain (WG) in kilograms (Kg).

After five days without the use of EE, the devices were reinstalled in bays for blood collection procedures, performed from 8:00 to 10:00 am in a population of six animals from stalls with incidence of sunlight and six animals from stalls without incidence of sunlight. Samples were immediately sent to the Laboratory of Clinical Pathology from UFPI, where blood samples were processed at a maximum of two hours after collected.

For evaluation of blood parameters $8 \mathrm{~mL}$ of venous blood were collected by jugular puncture with syringes and quickly transferred into tubes: the first tube with $4 \mathrm{~mL}$ capacity, containing EDTA anticoagulant (ethylenediaminetetraacetic acid) sprayed on the tube walls, to obtain whole blood, required to determine hematocrit and hemoglobin; and the second tube with $2.5 \mathrm{~mL}$ capacity, containing an coagulating accelerator and separating gel, which was centrifuged at $2.500 \mathrm{rpm} / 5$ minutes after sampling, in order to separate serum and subsequently determination of other blood biochemical constituents.

The blood count was achieved by counting the number of red blood cells, white blood cell count and hemoglobin concentration and was performed in automatic cell counter (CC530-CELM-Company Equip of Modern Laboratories, Barueri-SP). Determination of the packed cell volume (CV) was performed by the microhematocrit method; calculating the mean corpuscular volume (MCV) and mean corpuscular hemoglobin concentration (MCHC). The determination of plasma total protein (PTP) was performed by refractometry, after centrifuging blood in microhematocrit capillary tubes. All hematological techniques were performed according Hendrix (2006).

Differential leukocyte counts were expressed as percentage of the counting of 100 total cells by means of blood smears stained with Romanowsky's fast stain observed under a light microscope; the absolute number of each cell type was determined by multiplying the percentage fraction by the total leukocyte count, analyzes were performed according to Hendrix (2006).

Biochemical analyzes were performed in a semi-automatic biochemical analyzer (Espectrum BS ${ }^{\circledR}$-Celer, Belo Horizonte/MG, Brazil), using commercial kits. The serum albumin concentration was determined by the method of Bromocresol Green (Albumin ${ }^{\circledR}$-Labtest, Lagoa Santa/MG, Brazil) and serum total proteins (TP) by the Biuret method (Protein Total ${ }^{\circledR}$-Labtest). Glucose concentration was determined by the kinetic method of GOD-Trinder (Glucose Liquiform ${ }^{\circledR}$, Labtest).

The concentration of globulin was obtained by mathematical difference after determination of the total proteins and albumin, by subtracting the albumin from the total proteins (Busher, 1990; Chiquieri et al., 2007). For quality control testing, serum universal control was used (Qualitrol $1 \mathrm{H}^{\circledR}$-Labtest), according to the manufacturer's guidelines.

Air temperature (AT), air humidity (AH) and dew point temperature (DPT) were recorded with a digital thermohygrometer (SKILL-TEC) in the stalls. To measure the black globe temperature (BGT), a globe with 15 $\mathrm{cm}$ radius was installed at the height of the animals in a stall next to the experimental ones, painted with dark dye and provided with a mercury thermometer of $30 \mathrm{~cm}$, in which the temperature was measured 20 minutes after the beginning of the observation for each sampling collect. Black globe temperature was obtained with the equipment and procedures described.

The black globe temperature and humidity index (BGHI) were calculated according Buffington et al. (1981), using the equation:

$$
\mathrm{BGHI}=\mathrm{Bgt}+0.36 \mathrm{Dpt}-41.5
$$

Where,

$\mathrm{BGHI}=$ index of temperature and humidity, dimensionless; $\mathrm{Bgt}=$ black globe temperature, ${ }^{\circ} \mathrm{C} ; \mathrm{Dpt}=$ dew point temperature, ${ }^{\circ} \mathrm{C}$.

\subsection{Prophylactic and Food Management of Animals}

The animals were housed in pens with $10 \mathrm{~m}^{2}$ each, water was provided ad libitum and food was always available at the same schedule each day (8:00 and 16:00), with a diet formulated based on corn, soybean meal, and amino acids, vitamins and minerals to fulfill their nutritional requirements. Before housing the animals, procedures of disinfection, sanitary depopulation and daily dry cleaning of the stalls, were provided. 


\subsection{Model and Statistical Analysis}

$$
\mathrm{Y}_{\mathrm{ijk}}=\mu+\mathrm{E}_{\mathrm{i}}+\mathrm{I}_{\mathrm{j}}+(\mathrm{EI})_{\mathrm{ij}}+\mathrm{T}_{\mathrm{k}}+\varepsilon_{\mathrm{ijk}}
$$

Where,

$Y_{\mathrm{ijk}}=$ is the physiological response of animals related to the block $\mathrm{k}$ combining the level i factor of $\mathrm{E}$ to the level $\mathrm{j}$ factor of $\mathrm{I} ; \mu=\mathrm{It}$ is the average of all experimental units for $\mathrm{Y}_{\mathrm{ijk}} ; \mathrm{E}_{\mathrm{i}}=$ random effect of the animal ith with environmental enrichment (1 and 2); $I_{j}=$ It is the fixed animals jth effect with the presence or absence of insolation (1 and 2); $(E I)_{i j}=$ effect of environmental enrichment of the ith animal belonging to the jth animal with insolation; $\mathrm{I}_{\mathrm{k}}=$ fixed effect of the kth block represented by shifts $(1$ and 2$)$; and $\varepsilon_{\mathrm{ijk}}=$ is the residue including the random error.

Data were subjected to analysis of variance, the residue variance homogeneity test and correlation analysis. For analysis of variance and correlation the procedure: Proc GLM and CORR (Sas, 2003), were used. The results were compared by the Tukey test at $5 \%$ probability.

\section{Results and Discussion}

A maximum temperature of $38.20^{\circ} \mathrm{C}$, minimum temperature of $26.16^{\circ} \mathrm{C}$ and maximum and minimum humidity of $80.20 \%$ and $15.40 \%$, respectively, were observed, evidencing the variation between the shifts with high magnitude in the afternoon hours (Table 1). Thermal amplitude of $6.23{ }^{\circ} \mathrm{C}$ between the average values from the morning and the afternoon was verified.

Values obtained by Manno et al. (2005) showed that AT was higher in the morning shift because it exceeded the upper critical limit $\left(27^{\circ} \mathrm{C}\right)$ for this stage of swine breeding, thus considering such temperatures as negative to a better productive expression of these animals. Regarding the $\mathrm{AH}$, the afternoon shift had less $(\mathrm{p}>0.05)$ amount of water in the air, possibly because of the AT having achieved an average temperature of $36.22{ }^{\circ} \mathrm{C}$, thus rendering a dryer and uncomfortable air to breath. Miranda et al. (2012), working with pigs in nursery stage, considered that AH should remain between $50-70 \%$, with the optimal value for this breeding stage being of $70 \%$, according to Lima et al. (2011).

Table 1. Environmental variables registered within the facilities and physiological variables of pigs due to the shift

\begin{tabular}{lllllll}
\hline \multirow{2}{*}{ Shift } & \multicolumn{5}{c}{ Environmental and Physiological variables } \\
\cline { 2 - 6 } & AT $\left({ }^{\circ} \mathrm{C}\right)$ & AH $(\%)$ & BGHI & RT $\left({ }^{\circ} \mathrm{C}\right)$ & RR $(\mathrm{mov} / \mathrm{min})$ & HR $(\mathrm{bpm})$ \\
\hline Morning & $29.99^{\mathrm{b}}$ & $43.75^{\mathrm{a}}$ & $76.15^{\mathrm{b}}$ & $38.48^{\mathrm{b}}$ & $66.02^{\mathrm{b}}$ & $68.88^{\mathrm{b}}$ \\
Afternoon & $36.22^{\mathrm{a}}$ & $24.72^{\mathrm{b}}$ & $81.00^{\mathrm{a}}$ & $39.20^{\mathrm{a}}$ & $75.31^{\mathrm{a}}$ & $75.51^{\mathrm{a}}$ \\
\hline
\end{tabular}

Note. Means followed by the same letter in the column do not differ by Tukey test at $5 \%$ probability. Air temperature (AT); Air humidity (AH); Black globe temperature and humidity index (BGHI); Rectal temperature (RT); respiratory rate (RR); Heart rate (HR).

BGHI shows a possible influence $(\mathrm{p}<0.05)$ of climate variables in the thermal comfort of pigs. Tinôco et al. (2007) state that the upper limit of thermal comfort for pigs is 72. Manno et al. (2005) obtained BGHI values under heat conditions of 84.9 and 71.1 to comfort condition. Figure 01 shows the existence of this BGHI variation observed between the morning and afternoon shifts. 


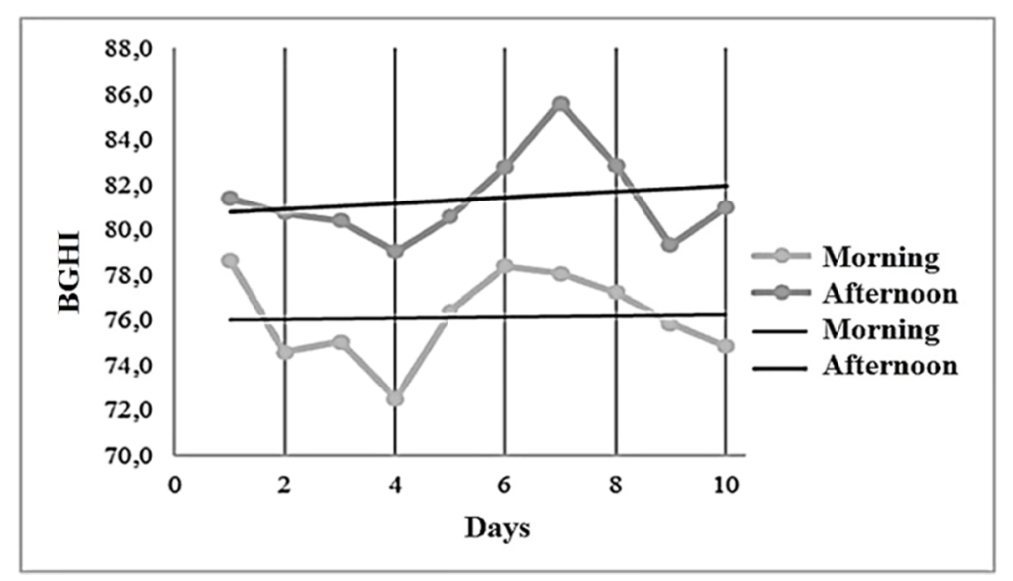

Figure 1. Variation of the Black Globe Temperature and and Humidity Index (BGHI) during morning and afternoon shifts

Figure 1 shows morning shift had values above the threshold (72) for pigs at an early stage, with only the fourth day of the experiment showing an optimal value to animal comfort, this is probably due to rain precipitation observed throughout this day. Lima et al. (2011) observed similar values of 73.7 in the morning shift and 77.25 in the afternoon shift. The afternoon shift proved to be stressful for the animals, especially during the seventh day, reaching values of 85 , that is to say $17.33 \%$ above the ideal value (Tinôco et al., 2007).

The afternoon shift was higher for RT $(\mathrm{p}<0.05)$ when compared to the morning shift, demonstrating the influence of climate. However, the animals remained within the thermal neutral range depending on the packaging provided by the installation. The range of rectal temperature considered ideal for comfort conditions remains between 38.6 and $39.3{ }^{\circ} \mathrm{C}$ (Kiefer et al., 2010). Farias et al. (2008) studied piglets of $29 \mathrm{~kg}$ with an average temperature of $30{ }^{\circ} \mathrm{C}$ shed and humidity of $63 \%$, in tropical environments, obtaining values of $39.68{ }^{\circ} \mathrm{C}$ RT in the morning shift and $39.78{ }^{\circ} \mathrm{C}$ in the afternoon shift, noticing that animals were using their mechanism of thermoregulation to achieve the homeothermal zone.

The RR magnitude in the afternoon $(p<0.05)$, with $10 \mathrm{mov} / \mathrm{min}$ above those of the morning shift, evidences the influence of climatic variables in the thermoregulatory characteristics, without negative effects for physiological well-being conditions. Kiefer et al. (2009) using 24 male pigs obtained from crosses of Landrace $\times$ (Landrace $\times$ Large White) with an average weight of $30.1 \pm 1.79 \mathrm{~kg}$, observed values with $45.90 \mathrm{mov} / \mathrm{min}$ when the animals were at comfortable thermal atmosphere, showing that animals in the present study had a high respiratory rate.

Analyzing the HR parameter, it was verified a $(p<0.05) 9.62 \%$ increment in the afternoon shift, with animals lying next to the water fountain, trying to lose heat by conduction to the stalls' floor. Häggmark et al. (2006) evaluated pigs (mean weight $40 \pm 1 \mathrm{~kg}$ ) had HR at rest, averaging $85 \mathrm{bpm}$. Loijens et al. (2002) reported that normal heart rate of pigs is $83 \pm 2 \mathrm{bpm}$.

The physiological variables as a function of the solar radiation and environmental enrichment are shown in Table 2. Weight gain (WG) in the presence of sunlight in the stalls, along with the absence of EE, resulted in low weight gain $(p<0.05)$, but in the absence of solar radiation and presence of $\mathrm{EE}(\mathrm{p}<0.05)$ a better weight gain was observed (17.9\% higher). This is probably due to the fact that enriched stalls were more attractive, especially those with less climate influence, prompting the curiosity of animals and allowing them to express the normal behavior of the species (Smulders et al., 2006; Temple et al., 2011). Kiefer et al. (2009) observed that thermal environments cause a reduction of $14.3 \%$ in food intake. Campos et al. (2010) obtained a better performance with the use of plastic bottles in the floor of the stalls. 
Table 2. Average values of physiological parameters of pigs in the presence or absence of environmental enrichment and insolation

\begin{tabular}{llll}
\hline \multirow{2}{*}{ Physiological variables } & Insolation & \multicolumn{2}{c}{ Environmental Enrichment } \\
\cline { 2 - 3 } & & Present & Absent \\
\hline WG $(\mathrm{kg})$ & Present & $3.81^{\mathrm{Ba}}$ & $3.20^{\mathrm{Bb}}$ \\
& Absent & $3.90^{\mathrm{Aa}}$ & $38.98 \pm 0.71^{\mathrm{Aa}}$ \\
\hline RT $\left({ }^{\circ} \mathrm{C}\right)$ & Present & $38.67 \pm 0.81^{\mathrm{Ab}}$ & $38.83 \pm 0.65^{\mathrm{Aa}}$ \\
\hline RR $(\mathrm{mov} / \mathrm{min})$ & Absent & $38.86 \pm 0.75^{\mathrm{Aa}}$ & $79.10 \pm 16.50^{\mathrm{Aa}}$ \\
& Present & $67.33 \pm 9.96 \mathrm{~A}^{\mathrm{b}^{\mathrm{ba}}}$ & $65.81 \pm 12.10^{\mathrm{Bb}}$ \\
\hline HR $(\mathrm{bpm})$ & Absent & $70.43 \pm 11.74 \mathrm{~A}^{\mathrm{a}}$ & $73.90 \pm 9.51^{\mathrm{Aa}}$ \\
& Present & $70.71 \pm 9.71^{\mathrm{Aa}}$ & $70.95 \pm 10.63^{\mathrm{Aa}}$ \\
\hline
\end{tabular}

Note. Means followed by the same lowercase and uppercase on the line in the column do not differ by Tukey test at 5\% significance. Weight gain (WG); Rectal temperature (E); Respiratory rate (RR); Heart rate (HR).

The use of EE decreased the RT $(p<0.05)$ due to the interaction of animals with plastic bottles, resulting in reduction of fights among animals. Animals under EE showed behavioral evidences of better welfare (Campos et al., 2010). Insolation did not influence RT ( $p>0.05)$, possibly because the animals remained in places where the stalls did not received sunlight, thus avoiding direct exposure to sunlight as well as allowing heat exchange with the stall's floor by conduction.

RR was reduced $(p<0.05)$ in the presence of EE, however, with insolation the animals had to use a greater portion of that variable to lose heat to the environment. In the absence of insolation, EE caused an increase in RR, a fact that was probably due to this variable have been triggered above the normal range for this stage, mainly in the afternoon shift, Manno et al. (2006) obtained values of $48 \pm 8 \mathrm{mov} / \mathrm{min}$ for RR in thermal comfort environment $\left(22^{\circ} \mathrm{C}\right)$ and feeding at will.

Insolation with EE did not affect $(\mathrm{p}>0.05) \mathrm{HR}$, once this variable have remained within its normal range, however the presence of EE provided a reduction $(p>0.05)$ of HR, consequently, the use of plastic bottles is considered beneficial as a method to propitiate a more attractive and less monotonous environment to the animals. Costa et al. (2009) have assessed heart rates between 65 and 90 bpm, with animals at rest in a farm, specifying that animals in this study were in a normal HR range (Lewis et al., 2008).

Correlation between physiological and environmental parameters, and EE are shown in Table 3. AT correlated positively with RR (0.35), HR (0.38) and RT (49), denoting that animals were influenced by the installation's inner microclimate. The increase of AT promoted the utilization increment of these thermoregulatory mechanisms, confirming results obtained from shifts, as shown in Table 1. Kiefer et al. (2009) reported that the average temperature of air can be considered as thermoneutral temperature once it remains between 18 and $26^{\circ} \mathrm{C}$, well below the values found in this study.

Table 3. Correlation between physiological and environmental parameters, and environmental enrichment in different shifts

\begin{tabular}{lllllll}
\hline Variables & HR & RT & AT & AH & SHIFT & WG \\
\hline RR & 0.34 & 0.26 & 0.35 & -0.34 & 0.33 & -0.32 \\
HR & & 0.35 & 0.38 & -0.37 & 0.31 & -0.07 \\
RT & & 0.49 & -0.42 & 0.48 & -0.10 \\
AT & & & -0.82 & 0.88 & 0 \\
AH & & & & -0.71 & 0 \\
EE & & & & & 0.68
\end{tabular}

Note. Heart rate (HR); Rectal temperature (RT); Respiratory rate (RR); Air temperature (AT); Air humidity (AH); Black globe temperature and humidity index (BGHI); Weight gain (WG); Environmental Enrichment (EE). 
AH was negatively correlated with RR (-0.34), HR (-0.37) and RT (-0.42), demonstrating that the animals activated their thermoregulatory mechanisms to a greater extent, as a reductionin the percentage of air moisture occurred, a result similar to AT (-0.82), but in the opposite direction, indicating that the increase in temperature caused a reduction of humidity, with AH values lower than $50 \%$ being considered uncomfortable for animals in nursery stage (Miranda et al., 2012).

Shift displayed a positive correlation with RR (0.33), HR (0.31) and RT (0.48), evidencing it affects animal welfare, resulting in a larger utilization of the thermoregulatory mechanisms, especially in the afternoon (Table 1 ), as a result, the animal spends energy to keep thermal comfort reducing the energy used in production.

WG was negatively correlated with RR (-0.32) and positive correlated with EE (0.68). Weight gain is considered adequate when the animal is not using thermoregulatory mechanisms. The presence of EE resulted in better weight gain due to the plastic bottles have stimulated the animals' holding capacity, and therefore, they fed better One method to assess environmental enrichment is to check the intensity of the interaction that reflects on their importance to key motivational systems such as exploration, games and food (Weerd \& Day, 2009).

Insolation and EE did not affect ( $p>0.05$ ) blood parameters (Table 4), however, for the packed cell volume (CV) the presence of EE resulted in a slight decrease, but without clinical significance, since according Weiss \& Wardrop 2010 it was within the range considered normal for pigs (37-44\%) in nursery stage The lack of influence from sunlight and environmental enrichment in blood parameters may be explained due to the animals being receiving food and water ad libitum.

Regarding TP and albumin, Silva et al. (2012) found values of $4.77 \mathrm{~g} / \mathrm{dL}$ TP and $2.27 \mathrm{~g} / \mathrm{dL}$ of albumin, Moreira et al. (2014) obtained a value of $7.02 \mathrm{~g} / \mathrm{dL}$ of TP and Rocha et al. (2012) obtained a value of $4.14 \mathrm{~g} / \mathrm{dL}$ albumin, with the range considered ideal for this protein being among 1.9-3.9 g/dL (Kaneko et al., 2008). Values below the optimal range of 6-8 g/dL (Weiss \& Wardrop, 2010) were observed for TP, due to the reference values being not regional, as well as due to the nutritional management used in each specifically production system, independently from the type of packaging (insolation or EE).

Table 4. Blood Parameters: Biochemical analysis, red blood cell (RBC) and white blood cell (WBC) of pigs in the nursery stage as a function of insolation and environmental enrichment

\begin{tabular}{|c|c|c|c|c|}
\hline \multirow{2}{*}{ Variables } & \multicolumn{2}{|c|}{ Insolation } & \multicolumn{2}{|c|}{ Environmental Enrichment } \\
\hline & Present & Absent & Present & Absent \\
\hline \multicolumn{5}{|c|}{ Biochemical analysis } \\
\hline $\mathrm{TP}(\mathrm{g} / \mathrm{dL})$ & $5.67^{\mathrm{a}}$ & $5.46^{\mathrm{a}}$ & $5.53^{\mathrm{A}}$ & $5.61^{\mathrm{A}}$ \\
\hline Albumin (g/dL) & $3.22^{\mathrm{a}}$ & $3.12^{\mathrm{a}}$ & $3.12^{\mathrm{A}}$ & $3.23^{\mathrm{A}}$ \\
\hline Globulin (g/dL) & $2.40^{\mathrm{a}}$ & $2.34^{\mathrm{a}}$ & $2.37^{\mathrm{A}}$ & $2.37^{\mathrm{A}}$ \\
\hline Glucose (mg/dL) & $95.99^{\mathrm{a}}$ & $103.70^{\mathrm{a}}$ & $102.64^{\mathrm{A}}$ & $96.45^{\mathrm{A}}$ \\
\hline \multicolumn{5}{|l|}{$R B C$} \\
\hline $\mathrm{CV}(\%)$ & $37.50^{\mathrm{a}}$ & $38.25^{\mathrm{a}}$ & $36.92^{\mathrm{B}}$ & $38.76^{\mathrm{A}}$ \\
\hline PTP(g/dL) & $6.05^{\mathrm{a}}$ & $6.25^{\mathrm{a}}$ & $6.16^{\mathrm{A}}$ & $6.13^{\mathrm{A}}$ \\
\hline $\mathrm{He}\left(10^{6} / \mu \mathrm{L}\right)$ & $7.08^{\mathrm{a}}$ & $7.32^{\mathrm{a}}$ & $7.08^{\mathrm{A}}$ & $7.31^{\mathrm{A}}$ \\
\hline $\mathrm{Hb}(\mathrm{g} / \mathrm{dL})$ & $11.46^{\mathrm{a}}$ & $11.78^{\mathrm{a}}$ & $11.47^{\mathrm{A}}$ & $11.74^{\mathrm{A}}$ \\
\hline MCV (fL) & $53.00^{\mathrm{a}}$ & $52.35^{\mathrm{a}}$ & $52.36^{\mathrm{A}}$ & $53.04^{\mathrm{A}}$ \\
\hline $\mathrm{MCHC}(\%)$ & $30.38^{\mathrm{a}}$ & $30.65^{\mathrm{a}}$ & $30.94^{\mathrm{A}}$ & $30.07^{\mathrm{A}}$ \\
\hline \multicolumn{5}{|l|}{$W B C\left(10^{3} / \mu L\right)$} \\
\hline Total leukocytes & $12.60^{\mathrm{a}}$ & $11.24^{\mathrm{a}}$ & $12.44^{\mathrm{A}}$ & $11.50^{\mathrm{A}}$ \\
\hline Rods & $0.05^{\mathrm{a}}$ & $0.00^{\mathrm{a}}$ & $0.03^{\mathrm{A}}$ & $0.02^{\mathrm{A}}$ \\
\hline Targeted & $3.14^{\mathrm{a}}$ & $2.93^{\mathrm{a}}$ & $3.07^{\mathrm{A}}$ & $3.01^{\mathrm{A}}$ \\
\hline Lymphocytes & $9.00^{\mathrm{a}}$ & $7.84^{\mathrm{a}}$ & $8.82^{\mathrm{A}}$ & $8.11^{\mathrm{A}}$ \\
\hline Eosinophils & $0.11^{\mathrm{a}}$ & $0.16^{\mathrm{a}}$ & $0.16^{\mathrm{A}}$ & $0.11^{\mathrm{A}}$ \\
\hline Basophils & $0.00^{\mathrm{a}}$ & $0.01^{\mathrm{a}}$ & $0.01^{\mathrm{A}}$ & $0.00^{\mathrm{A}}$ \\
\hline Monocytes & $0.27^{\mathrm{a}}$ & $0.29^{\mathrm{a}}$ & $0.31^{\mathrm{A}}$ & $0.26^{\mathrm{A}}$ \\
\hline
\end{tabular}

Note. Means followed by the same lowercase or uppercase letter on the line do not differ by Tukey test at $5 \%$ significance. $\mathrm{TP}=$ Total protein $\mathrm{CV}=$ Cell volume; $\mathrm{PTP}=$ Plasma total protein $\mathrm{He}=$ Erythrocytes $; \mathrm{Hb}=$ Hemoglobin; $\mathrm{MCV}=$ Mean corpuscular volume; $\mathrm{MCHC}=$ Mean corpuscular hemoglobin concentration . 
With respect to glucose and globulin, authors found values of $114.2 \mathrm{mg} / \mathrm{dL}$ of glucose (Moreira et al., 2014); $109.16 \mathrm{mg} / \mathrm{dL}$ of glucose (Rocha et al., 2012) and $4.34 \pm 0.96 \mathrm{~g} / \mathrm{dL}$ globulin (Chiquieri et al., 2007). The levels of these animal blood constituents were within the ideal range of $85-150 \mathrm{~g} / \mathrm{dL}$ for glucose but outside the ideal 5.29-6.43 g/dL for globulin (Kaneko et al., 2008), possibly due to variations between breeds, as well as due to different immunization protocols.

Dalto et al. (2011), analyzing the hematological profile of 35 days old Penarlan pigs, obtained CV values of $37.57 \%$ and $\mathrm{He}$ of $8.05 \pm 0.16 \times 10^{6} / \mu \mathrm{L}$, while Silva et al. (2012) obtained $31.41 \% \mathrm{CV}$ and $5.56 \times 10^{6} / \mu \mathrm{L} \mathrm{He}$. Normal values for pigs' erythrogram in the nursery stage are around $37-44 \%$ of CV, 7-8 g/dL of PTP and 5.9-6.8 $\times 10^{6} / \mu \mathrm{L}$ of $\mathrm{He}$ (Weiss \& Wardrop, 2010). The PTP and He were below the ideal range for pigs at this stage, this may be due to the probable hemolysis of red blood cells, as a result of stressing factors associated with the restraint and blood collecting.

Normal values for pigs in nursery stage are between 11.3-13.3 g/dL of Hb; 62-68 fL of MCV and 28-32\% of MCHC (Weiss \& Wardrop, 2010). Moreira et al. (2006) observed MCV of $56.04 \mathrm{fL}$ for pigs at an early stage, which were higher when compared to the present study. MCV and $\mathrm{Hb}$ were below the ideal values, probably due to the age of the animals and the kind of nutritional management employed.

Regarding the WBC, values different from those obtained by Huaynate et al. (2014) were observed. These authors reported values of $16.07 \times 10^{3} / \mu \mathrm{L}$ of leukocytes; $0.41 \times 10^{3} / \mu \mathrm{L}$ of band neutrophils; $6.18 \times 10^{3} / \mu \mathrm{L}$ of segmented neutrophils, however normal leukocytes in pig tracks in the nursery stage are on average of 12.7-20.9 $\times 10^{3} / \mu \mathrm{L}$ total leukocytes, $0-1 \times 10^{3} / \mu \mathrm{L}$ of band neutrophils and 3.55-8.9 $\times 10^{3} / \mu \mathrm{L}$ segmented neutrophils (Weiss \& Wardrop, 2010). The lower values observed in the present study may be a result of the genetic variability within the animals tested.

The values obtained for lymphocytes, eosinophils, basophils, and monocytes were within the normal range for pigs in the nursery stage, with values of 5.8-14.21 $\times 10^{3} / \mu \mathrm{L}$ lymphocytes, $0.44-2.92 \times 10^{3} / \mu \mathrm{L}$ eosinophils, $0-0.31$ $\times 10^{3} / \mu \mathrm{L}$ basophils and $0.3-2.19 \times 10^{3} / \mu \mathrm{L}$ monocytes (Weiss \& Wardrop, 2010), indicating that animals were in good health conditions with no signs of inflammation and/or infections.

\section{Conclusion}

The use of plastic bottles as a form of enrichment provides physiological well-being and weight gain, especially for animals that received the incidence of sun light. For animals that remain all the time in the shade the use of enrichment is less effective.

Pigs are influenced by the environmental parameters mainly in the afternoon, reducing the welfare and weight gain, thus the animals show thermal stress. Correlations demonstrate that the presence of environmental enrichment reduces some of the stress provided by the environment, however insolation and environmental enrichment does not provide relevant influences on blood parameters of pigs.

\section{Acknowledgements}

To God, through his infinite love, granting me the gift of life and the strength to pursue resolutely in pursuit of my personal and professional achievements. To the Federal University of Piauí Campus Professor Cinobelina Elvas, Bom Jesus Technical School (CTBJ) and to the Post Graduation Program Animal Science for the opportunity to accomplish my Master's degree course. To the Coordination of Improvement of Higher Education Personnel (CAPES), for the financial support through the granting of the scholarship.

\section{References}

Andrade Jr, A. S., Bastos, E. A., Barros, A. H. C., Silva, C. O., \& Gomes, A. A. N. (2005). Classificação climática e regionalização do semi-árido do Estado do Piauí sob cenários pluviométricos distintos. Revista Ciência Agronômica, 36(2), 143-151.

Buffington, D. E., Collazo-Arocho, A., Canton, G. H., Pitt, D., Thatcher, W. W., \& Collier, R. J. (1981). Black globe-humidity index (BGHI) as comfort equation for dairy cows. Transaction of the ASAE, 24(3), 711-714. https://doi.org/10.13031/2013.34325

Busher, J. T. (1990). Chapter 101Serum Albumin and Globulin. In H. K. Walker, W. D. Hall, \& J. W. Hurst (Eds.), Clinical Methods: The History, Physical, and Laboratory Examinations (3th ed.). Boston: Butterworths.

Campos, J. A., Tinôco, I. F. F., Silva, F. F., Pupa, J. M. R., \& Silva, I. J. O. (2010). Enriquecimento ambiental para leitões na fase de creche advindos de desmame aos 21 e 28 dias. Revista Brasileira de Ciências Agrárias, 5(2), 272-27. https://doi.org/10.5039/agraria.v5i2a660 
Chiquieri, J., Soares, R. T. R. N., Hurtado Nery, V. L., Carvalho, E. C. Q., \& Costa, A. P. D. (2007). Bioquímica sangüínea e altura das vilosidades intestinais de suínos alimentados com adição de probiótico, prebiótico e antibiótico. Revista Brasileira de Saúde e Produção Animal, 8(2), 97-104.

Costa, O. A. D., Ludke, J. V., Coldebella, A., Kich, J. D., Costa, M. J. R. P., Faucitano, L., \& Peloso, J. V. (2009). Efeito do manejo pré-abate sobre alguns parâmetros fisiológicos em fêmeas suínas pesadas. Ciência Rural, 39(3), 852-858. https://doi.org/10.1590/S0103-84782009000300033

Dalto, D. B., Silva, C. A., Bridi, A. M., Gavioli, D. F., Oliveira, E. R., Silva, R. A. M., ... Venâncio, E. J. (2011). Plasma sanguíneo desidratado na recuperação de leitões leves ao desmame: Desempenho zootécnico, perfil hematológico, freqüência de diarréia e viabilidade econômica. Semina. Ciências Agrárias, 3(2), 1989-2000. https://doi.org/10.5433/1679-0359.2011v32Suplp1989

Fagundes, A. C. A., Negrão, J. A., Silva, R. G., Gomes, J. D. F., Souza, L. W. O., \& Fukushima, R. S. (2008). Environmental temperature and serum cortisol levels in growing-finishing pigs. Brazilian Journal of Veterinary Research and Animal Science, 45, 136-140. https://doi.org/10.11606/S1413-95962008000 700019

Farias, L. A., Lopes, J. B, Figueirêdo, A. V., Albuquerque, D. M. N., Neto, A. A. A., \& Ramos, L. S. N. (2008). Pseudofruto do cajueiro (Anacardium occidentale L.) para suínos em crescimento: Metabolismo de nutrientes e desempenho. Ciência Animal Brasileira, 9(1), 100-109. Retrieved from https://www.revistas.ufg.br/vet/article/view/3673

Häggmark, S., Haneyb, M. F., Johanssonb, G., Biberb, B., \& Näslund, U. (2006). Vectorcardiographic ST deviations related to increased heart rate in the absence of ischemia in an experimental pig model. Journal of Electrocardiology, 39(2), 169-176. https://doi.org/10.1016/j.jelectrocard.2005.08.014

Hendrix, C. M. (2006). Procedimentos laboratoriais para técnicos veterinários (2nd ed.). São Paulo; Roca.

Huaynate, R. A. R, Thomaz, M. C., Santana, A. E., Masson, G. C. I. H., Amorim, A. B., Silva, S. Z., ... Budiño, F. E. L. (2014). Probiótico em dietas de suínos sobre os parâmetros sanguíneos e digestibilidade de rações. Semina. Ciências Agrárias, 35(3), 1627-1636. https://doi.org/10.5433/1679-0359.2014v35n3p1627

Kaneko, J. J., Harvey, J. W., \& Bruss, M. L. (2008). Clinical Biochemistry of Domestic Animals (6th ed.). Academic Press.

Kiefer, C., Meignen, B. C. G., Sanches, J. F., \& Carrijo, A. S. (2009). Resposta de suínos em crescimento mantidos em diferentes temperaturas. Archivos de Zootecnia, 58(221), 55-64. https://doi.org/10.4321/ S0004-05922009000100006

Kiefer, C., Moura, M. S., Silva, E. A., Santos, A. P., Silva, C. M., Luz, M. F., \& Nantes, C. L. (2010). Respostas de suínos em terminação mantidos em diferentes ambientes térmicos. Revista Brasileira de Saúde e Produção Animal, 11(2), 496-504.

Lewis, C. R. G., Hulbert, L. E., \& Mcglone, J. J. (2008). Novelty causes elevated heart rate and immune changes in pigs exposed to handling, alleys, and ramps. Livestock Science, 116(1-3), 338-341. https://doi.org/10.1016/j.livsci.2008.02.014

Lima, A. L., Oliveira, R. F. M., Donzele, J. L., Fernandes, H. C., Campos, P. H. R. F., \& Antunes, M. V. L. (2011). Resfriamento do piso da maternidade para porcas em lactação no verão. Revista Brasileira de Zootecnia, 40(4), 804-811. https://doi.org/10.1590/S1516-35982011000400014

Loijens, L. W. S., Janssens, C. J. J. G., Schouten, W. G. P., \& Wiegant, V. M. (2002). Opioid activity in behavioral and heart rate responses of tethered pigs to acute stress. Physiology \& Behavior, 75, 621-626. https://doi.org/10.1016/S0031-9384(01)00650-3

Manno, M. C., Oliveira, R. F. M., Donzele, J. L., Ferreira, A. S., Oliveira, W. P., Lima, K. R. S., \& Vieira Vaz, R. G. M. (2005). Efeito da Temperatura Ambiente sobre o Desempenho de Suínos dos 15 aos $30 \mathrm{~kg}$. Revista Brasileira de Zootecnia, 34(6), 1963-1970. https://doi.org/10.1590/S1516-35982005000600021

Manno, M. C., Oliveira, R. F. M., Donzele, J. L., Oliveira, W. P., Vieira Vaz, R. G. M., Silva, B. A. N., ... Lima, K. R. S. (2006). Efeitos da temperatura ambiente sobre o desempenho de suínos dos 30 aos $60 \mathrm{~kg}$. Revista Brasileira de Zootecnia, 35(2), 471-477. https://doi.org/10.1590/S1516-35982006000200019

Miranda, K. O. S., Borges, G., Menegale, V. L. C., \& Silva, I. J. O. (2012). Efeito das condições ambientais no nível de ruído emitido por leitões. Engenharia Agrícola, 32(3), 435-445. https://doi.org/10.1590/ S0100-69162012000300003 
Moreira, F. R. C., Costa, A. N., Martins, T. D. D., Silva, J. H. V., Medeiros, H. R., \& Cruz, G. R. B. (2014). Substituição parcial do milho por sorgo granífero na alimentação de suínos nas fases de creche, crescimento e terminação. Revista Brasileia de Saúde e Produção Animal, 15(1), 94-107. https://doi.org/10.1590/ S1519-99402014000100013

Moreira, I., Sartori, I. M., Paiano, D., Martins, R. M., \& Oliveira, G. C. (2006). Utilização do farelo de algodão, com ou sem a adição de ferro, na alimentação de leitões na fase inicial (15-30 kg). Revista Brasileira de Zootecnia, 35(3), 1077-1084. https://doi.org/10.1590/S1516-35982006000400019

Poletto, R., Janczak A. W., Marchant-Forde, R. M., Marchant-Forde, J. N., Matthews, D. L., Dowell, C. A., ... Lay Jr, D. C. (2011). Identification of low and frequency ranges for heart rate variability and blood pressure variability analyses using pharmacological autonomic blockade with atropine and propranolol in suine. Physiology \& Behavior, 103(2), 188-196. https://doi.org/10.1016/j.physbeh.2011.01.019

Rocha, G. C., Donzele, J. L, Oliveira, R. F. M., Silva, F. C. O., Kiefer, C., Brustolini, P. C., ... Alebrante, L. (2012a). Avaliação dos níveis de zeólita em dietas para suínos em fase de crescimento e terminação. Revista Brasileira de Zootecnia, 41(1), 111-117. https://doi.org/10.1590/S1516-35982012000100017

SAS. (2003). Institute SAS (Statistical Analysis System). User's Guide. Cary NC: SAS Institute Inc.

Silva, S. Z., Thomaz, M. C., Watanabe, P. H., Huaynate, R. A. R., Ruiz, U. S., Pascoal, L. A. F., ... Masson, G. C. I. H. (2012). Mananoligossacarídeo em dietas para leitões desmamados. Brazilian Journal of Veterinary Research and Animal Science, 49(2), 102-110. https://doi.org/10.11606/issn.2318-3659.v49i2p102-110

Smulders, D., Verbeke, G., Mormède, P., \& Geers, R. (2006). Validation of a behavioral observation tool to assess pig welfare. Physiology \& Behavior, 89(3), 438-447. https://doi.org/10.1016/j.physbeh.2006.07.002

Temple, D., Manteca, X., Velarde, A., \& Dalmau, A. (2011). Assessment of animal welfare through behavioural parameters in Iberian pigs in intensive and extensive conditions. Applied Animal Behaviour Science, 131(1-2), 29-39. https://doi.org/10.1016/j.applanim.2011.01.013

Tinôco, I. F. F, Souza, C. F., Oliveira, P. A. V., Paulo, R. M., Campos, J. A., Carvalho, C. C. S., \& Cordeiro, M. B. (2007). Avaliação do índice de temperatura de globo negro e umidade e desempenho de suínos nas fases de crescimento e terminação criados em sistemas de camas sobrepostas em condições de verão. Revista Brasileira de Zootecnia, 36(5), 1624-1629. https://doi.org/10.1590/S1516-35982007000700022

Velarde, A., Fàbrega, E., Blanco-Penedo, I., \& Dalmau, A. (2015). Animal welfare towards sustainability in pork meat production. Meat Science, 109, 13-17. https://doi.org/10.1016/j.meatsci.2015.05.010

Weerd, H. A. V., \& Day, J. E. L. (2009). A review of environmental enrichment for pigs housed in intensive housing systems. Applied Animal Behaviour Science, 116, 1-20. https://doi.org/10.1016/j.applanim.2008. 08.001

Weiss, D. J. (2010). Chapter 109: Hematology of the pig. In D. J. Weiss \& K. J. Wardrop (Eds.), Schalm's veterinary hematology (6th ed., pp. 843-850). Ames, IA: Wiley-Blackwell.

\section{Copyrights}

Copyright for this article is retained by the author(s), with first publication rights granted to the journal.

This is an open-access article distributed under the terms and conditions of the Creative Commons Attribution license (http://creativecommons.org/licenses/by/4.0/). 